\title{
Vacuolar Protein Sorting-Associated Protein 18
}

National Cancer Institute

\section{Source}

National Cancer Institute. Vacuolar Protein Sorting-Associated Protein 18. NCI

Thesaurus. Code C105601.

Vacuolar protein sorting-associated protein 18 (973 aa, $110 \mathrm{kDa}$ ) is encoded by the human VPS18 gene. This protein is involved in vesicle-mediated protein trafficking. 